ORIGINAL ARTICLE

\title{
Adhesion of water stressed Helicobacter pylori to abiotic surfaces
}

\author{
N.F. Azevedo ${ }^{1,2}$, A.P. Pacheco ${ }^{1}$, C.W. Keevil ${ }^{2}$ and M.J. Vieira ${ }^{1}$ \\ 1 Centro de Engenharia Biológica, Universidade do Minho, Braga, Portugal \\ 2 School of Biological Sciences, University of Southampton, Southampton, UK
}

\author{
Keywords \\ adhesion, copper, Helicobacter pylori, \\ morphology, substrata, water. \\ Correspondence \\ Maria J. Vieira, Centro de Engenharia \\ Biologica, Universidade do Minho, 4710-057 \\ Braga, Portugal. \\ E-mail:mjv@deb.uminho.pt
}

2005/1222: received 13 October 2005, revised 15 December 2005 and accepted 13 January 2006

doi:10.1111/j.1365-2672.2006.03029.x

\begin{abstract}
Aim: The main aim of this work was to study and compare the adhesion of water exposed Helicobacter pylori to six different substrata and correlate any changes in morphology, physiology, ability to form aggregates and cultivability when in the planktonic or in the sessile phase.

Methods and Results: The number of total cells adhered for different water exposure times and modifications in the cell shape were evaluated using epifluorescence and scanning electron microscopy, and physiology assessed using Syto9 and propidium iodide (PI) cellular uptake. All abiotic surfaces were rapidly colonized by $H$. pylori, and colonization appeared to reach a steady state after $96 \mathrm{~h}$ with levels ranging from $2.3 \times 10^{6}$ to $3.6 \times 10^{6}$ total cells $\mathrm{cm}^{-2}$. Cell morphology was largely dependent on the support material, with spiral bacteria, associated with the infectious form of $H$. pylori, subsisting in a higher percentage on nonpolymeric substrata. Also, sessile bacteria were generally able to retain the spiral shape for longer when compared with planktonic bacteria, which became coccoid more quickly. The formation of large aggregates, which may act as a protection mechanism against the negative impact of the stressful external environmental conditions, was mostly observed on the surface of copper coupons. However, Syto9 and PI staining indicates that most of H. pylori attached to copper or SS304 have a compromised cell membrane after only $48 \mathrm{~h}$. Cultivability methods were only able to detect the bacteria up to the $2 \mathrm{~h}$

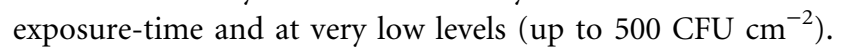

Conclusions: The fact that the pathogen is able to adhere, retain the spiral morphology for longer and form large aggregates when attached to different plumbing materials appeared to point to pipe materials in general, and copper plumbing in particular, as a possible reservoir of virulent $H$. pylori in water distribution systems. However, the Syto9/PI staining results and cultivability methods indicate that the attached $H$. pylori cells quickly enter in a nonviable physiological state.

Significance and Impact of the Study: This represents the first study of $H$. pylori behaviour in water-exposed abiotic surfaces. It suggests that co-aggrega-

tion with the autochthonous heterotrophic consortia present in water is neces-
sary for a longer survival of the pathogen in biofilms associated to drinking

tion with the autochthonous heterotrophic consortia present in water is neces-
sary for a longer survival of the pathogen in biofilms associated to drinking water systems.
\end{abstract}

\section{Introduction}

Helicobacter pylori is a Gram-negative, flagellated bacterium closely related to Campylobacter spp. It is the etiological agent of gastritis, peptic and duodenal ulcer disease. This pathogen can assume either a spiral or coccoid form, passing through an intermediate U-shape during the conversion from one form to another (Anderson 
and Wadstrom 2001). Transformation to the coccoid form can be induced by exposing the micro-organism to suboptimal conditions, such as nutrient deprivation (West et al. 1990), and prolonged incubation (Moshkowitz et al. 1994), suggesting that these forms are a dormant stage of $H$. pylori and might constitute a survival strategy in adverse environmental conditions (Citterio et al. 2004). Spiral shape is usually associated with the infectious form of the bacterium (Anderson and Wadstrom 2001).

So far, the mechanisms of how H. pylori is transmitted, and where in the environment outside the human host the organism resides has been unclear (Parsonnet et al. 1999; Mitchell and Megraud 2002); however, there is a mounting evidence that water is one of the vehicles of infection (Hegarty et al. 1999; Mazari-Hiriart et al. 2001; Lu et al. 2002; Karita et al. 2003; Azevedo et al. 2004). It is therefore important to study H. pylori behaviour in water systems and also in water-associated biofilms, where the bacteria can have a better chance of survival in the microenvironments generated by the heterogeneous structure and activity of the complex consortia (Keevil 2003). In fact, this micro-organism has been found to have the capacity of incorporating into lab-grown biofilms (Mackay et al. 1999; Azevedo et al. 2003b) and was also detected in real drinking water biofilms using molecular techniques (Park et al. 2001; Bunn et al. 2002; Watson et al. 2004). Substratum material is one of the factors affecting the growth of biofilms. Abiotic surfaces have been shown to not only influence the attachment of total bacteria (Pedersen 1990; Kerr et al. 1999), but also the attachment of particular pathogens (Rogers et al. 1994).

This work tried to establish to what extent H. pylori would be able to attach to different materials commonly used in drinking water systems and if any differences in cell morphology and ability to form aggregates could be found for different materials and between adhered and planktonic cells.

\section{Materials and methods}

\section{Culture maintenance}

Helicobacter pylori NCTC 11637 was maintained on Columbia Agar (Oxoid, Basingstoke, UK) supplemented with 5\% (v/v) defribinated horse blood (Biomérieux, Marcy l'Etoile, France) and 1\% (v/v) fetal calf serum (Merck, Hohenbrumn, Germany). Plates were incubated at $37^{\circ} \mathrm{C}$ in a Genbox jar 2.51 (Biomérieux) under microaerophilic conditions created using a Genbox microaer (Biomérieux) and streaked onto fresh plates every 2 or 3 days.

\section{Test surfaces preparation}

Coupons measuring $2 \times 2 \mathrm{~cm}$ were prepared at the Centro de Engenharia Biológica from stainless steel 304 (F. Ramada, Ovar, Portugal) and 316 (F. Ramada), copper (Companhia Portuguesa do Cobre, Porto, Portugal), polyvinyl chloride (PVC; Neves e Neves, Trofa, Portugal), polypropylene (PP; Vimágua, Guimarães, Portugal) and glass (slides $75 \times 25 \mathrm{~mm}$, Moreira Costa e Santos, Porto, Portugal). Copper coupons were polished with an alumina suspension (Struers, Copenhagen, Denmark). All materials were immersed in a solution of $5 \%(\mathrm{v} / \mathrm{v})$ commercial detergent (Top Neils, Tengelmann Portugal, Sintra, Portugal) and prewarmed distilled water for $30 \mathrm{~min}$ while gently mixed. To remove any remaining detergent, coupons were rinsed five times in ultra-pure water and air-dried. They were subsequently immersed in 90\% (v/v) ethanol for $30 \mathrm{~min}$, except PVC and PP that were only immersed for $10 \mathrm{~s}$. After being rinsed with ultra-pure water, air-dried and wrapped in foil, SS304, SS316, copper and glass coupons were autoclaved for $15 \mathrm{~min}$ at $121^{\circ} \mathrm{C}$, whereas PP and PVC were heated for $20 \mathrm{~min}$ at $80^{\circ} \mathrm{C}$. Coupons were finally placed in wells of a 6-well tissue culture plate (Orange Scientific, Braine-l' Alleud, Belgium).

Suspension preparation, inoculation and culturable cell counts

Cells from two-day-old cultures were harvested from Columbia Agar plates, suspended in $10 \mathrm{ml}$ of autoclaved tap water and vortexed for $30 \mathrm{~s}$. This inoculum was then transferred to a sterile bioreactor containing $1000 \mathrm{ml}$ of autoclaved tap water, with a final concentration of approximately $10^{6} \mathrm{CFU} \mathrm{\textrm {ml } ^ { - 1 }}$. The bioreactor was maintained at room temperature $\left(24 \pm 2^{\circ} \mathrm{C}\right)$ and continuously stirred (120 rev $\min ^{-1}$ ) using a magnetic bar. After $10 \mathrm{~min}, 5 \mathrm{ml}$ of the suspension were dispensed in to each of the wells containing the coupons. At various times of exposure, one coupon of each material was removed from the well, rinsed three times in autoclaved tap water, and left to air-dry. For SS304, CFU of planktonic H. pylori was analysed temporally by plating an appropriate volume on to $H$. pylori special peptone agar (HPSPA) plates (Stevenson et al. 2000).

Total cell counts of planktonic and adhered bacteria and Live/Dead staining procedure

Total cell counts of planktonic bacteria (for SS304 only) were obtained by filtering 100-200 $\mu \mathrm{l}$ of the suspension in the well through a $25 \mathrm{~mm}$ black Nuclepore ${ }^{\circledR}$ polycarbonate membrane with a pore size of $0.2 \mu \mathrm{m}$ (Whatman, 
Kent, UK). After filtration, cells on the membrane were stained with $100 \mu \mathrm{g} \mathrm{ml}^{-1}$ 4,6-diamino-2-phenylindole (DAPI) (Sigma, St Louis, MO, USA) for $5 \mathrm{~min}$ and preparations were stored for up to 2 days in the dark before visualization. No significant decay of fluorescence was noticed during this time span. Cells were visualized under an epifluorescence microscope (Carl Zeiss, Hallbergmors, Germany) equipped with a filter block sensitive to DAPI fluorescence. A total of 20 fields were counted using an ocular grid and the average was used to calculate total cells per $\mathrm{ml}$ of sample. For smoothing and analysis purposes, results were transformed to $\log _{10}$ total cells per $\mathrm{ml}$ of sample.

Total cell counts of adhered bacteria were obtained by a similar method, but $80 \mu \mathrm{l}$ of the DAPI solution was applied directly to the substrata, which were then covered with a cover slip. For each coupon, 50 fields were counted and the results expressed as $\log _{10}$ total cells per $\mathrm{cm}^{2}$. At selected times, five fields were used to determine the proportion of spiral/coccoid bacteria either in the planktonic phase or when attached to the different materials.

To assess the membrane integrity of the sessile bacteria, the LIVE/DEAD BacLight kit (Molecular Probes, Eugene, OR, USA) was used (Boulos et al. 1999). The two reagents (i.e. Syto9 and propidium iodide) were prepared according to the manufacturer instructions, and mixed in equal proportions. The mixture was then applied to coupons of SS304 and copper with different times of exposure $(20 \mu \mathrm{l}$ per coupon), covered with a cover slip and incubated for $15 \mathrm{~min}$ in the dark. Cells were visualized under an epifluorescence microscope (Carl Zeiss, Germany) equipped with a filter block that simultaneously detected the two components of the mixture.

\section{Scanning electron microscopy}

Coupons with $192 \mathrm{~h}$ of exposure were immersed for $15 \mathrm{~min}$ in solutions with increasing concentrations of ethanol up to $100 \%(\mathrm{v} / \mathrm{v})$, and placed in a sealed desiccator. The coupons were mounted on aluminium stubs with carbon tape, sputter coated with gold and observed with a Leica Cambridge S-360 scanning electron microscope (SEM) (Leo, Cambridge, UK). The SEM was equipped with an X-ray analyser, which allowed the identification and quantification of certain atomic elements (such as oxygen) on the surface of the materials.

\section{Confirmative procedures and analysis of data}

Besides checking for typical colony morphology (i.e. round, translucent to yellowish, convex, 0·2-2 mm) (Anderson and Wadstrom 2001), hybridization with a specific peptide nucleic acid (PNA) probe to $16 \mathrm{~S}$ rRNA
(Azevedo et al. 2003a) was performed to confirm the identity of $H$. pylori isolated in the Petri dishes and adhered to the surfaces. For the comparison between different materials a one-way ANOva was used followed by a Bonferroni post hoc test and computations performed using SPSS (SPSS Inc., Chicago, IL, USA). Results were considered statistically relevant if $P \leq 0.05$.

\section{Results}

\section{Adhesion to different substrata}

All surfaces were readily colonized by $H$. pylori, with approximately $75 \%$ of the total number of cells obtained at the end of the experiment being obtained at the end of just $48 \mathrm{~h}$ of exposure (Table 1). It can also be observed that between 96 and $192 \mathrm{~h}$, the total number of cells remained nearly constant for all materials except for PP. It was therefore decided to calculate the average of these two points, considered to be in steady state. Copper and PP were found to contain the largest numbers of adhered H. pylori, whereas glass was found to have the lowest. However, one-way ANOva showed no statistically significant differences between the different pairs of materials ( $P>0.05$ for all cases). The small differences obtained (2.5\% difference between the most extreme case, PP and glass; $P=0 \cdot 16$ ) show that, up to $192 \mathrm{~h}$, the adhesion of $H$. pylori is not very dependent on the type of substratum used in terms of total cell counts. In all experiments, H. pylori presence in the surface was confirmed by PNA hybridization and no contaminations were observed.

Relationship between culturability, adhesion and viability staining

To verify whether any relationship existed between the culturability status of the bacteria and ability to attach to

Table 1 Adhesion of water-suspended Helicobacter pylori NCTC 11637 to different plumbing material substrata with time

\begin{tabular}{|c|c|c|c|c|c|c|}
\hline \multirow[b]{2}{*}{ Time (h) } & \multicolumn{6}{|c|}{$\log _{10}$ cells $\mathrm{cm}^{-2}$} \\
\hline & SS304 & SS316 & Copper & PVC & PP & Glass \\
\hline 0 & 0.00 & 0.00 & 0.00 & 0.00 & 0.00 & 0.00 \\
\hline 2 & $5 \cdot 19$ & $5 \cdot 34$ & $4 \cdot 70$ & $4 \cdot 51$ & $5 \cdot 26$ & $2 \cdot 92$ \\
\hline 6 & $5 \cdot 76$ & $5 \cdot 65$ & NA & $5 \cdot 79$ & NA & $5 \cdot 71$ \\
\hline 13 & 5.99 & $6 \cdot 08$ & $5 \cdot 12$ & 5.99 & $6 \cdot 12$ & $5 \cdot 68$ \\
\hline 24 & $6 \cdot 25$ & $6 \cdot 10$ & 5.98 & $6 \cdot 16$ & $6 \cdot 28$ & $5 \cdot 70$ \\
\hline 48 & $6 \cdot 35$ & $6 \cdot 23$ & $6 \cdot 35$ & $6 \cdot 35$ & $6 \cdot 35$ & $6 \cdot 22$ \\
\hline 96 & $6 \cdot 42$ & $6 \cdot 41$ & $6 \cdot 44$ & $6 \cdot 41$ & $6 \cdot 42$ & $6 \cdot 35$ \\
\hline 192 & $6 \cdot 44$ & $6 \cdot 40$ & $6 \cdot 47$ & $6 \cdot 41$ & $6 \cdot 56$ & $6 \cdot 36$ \\
\hline
\end{tabular}

PVC, polyvinyl chloride; PP, polypropylene; NA, not applicable. 
different substrata, the total and cultivable numbers of the bacteria in the planktonic phase were also followed. Culturable cells were below detection after $13 \mathrm{~h}$ (limit of

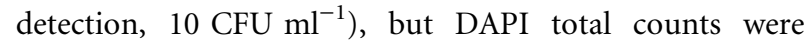
nearly constant for the time span of the experiment. It was also attempted to quantify the number of CFU attached to the coupons, but the methods tested to remove the cells (sonication and vortexing with glass beads) were only able to detect the bacteria at the $2 \mathrm{~h}$

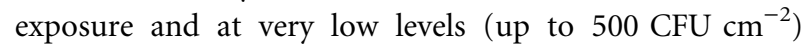
even though the efficiency of removal, as assessed by DAPI total counts before and after the detachment method, ranged between $60-70 \%$ for both methods. The levels of total planktonic bacteria did not decrease with time, which confirms the results obtained by Shahamat et al. (1993). Syto9/PI analysis of H. pylori attached to surfaces showed the large majority of cells starting to uptake PI after $48 \mathrm{~h}$, which is to be regarded as the beginning of damage occurring in cell membranes. Complete PI uptake was clearly observed in all cells at the end of only 1 week (Fig. 1), which, according to Boulos et al. (1999), implies seriously compromised membrane integrity and is therefore indicative of cell death. Although originally it was thought that PI uptake was independent of cell shape, closer observation suggested that coccoid bacteria took longer to stain completely or partially red. This indicates that the coccoid form constitutes a survival strategy in adverse environmental conditions, which is in agreement with some recently published studies (Saito et al. 2003; Citterio et al. 2004).

Cole et al. (2004) and Adams et al. (2003) also used Syto9/PI staining to evaluate the viability of $H$. pylori. Cole et al. indicated that brain heart infusion broth (BHIB)-exposed $H$. pylori cells of an actively growing biofilm (3-4 days old) were all alive, and that even at day 5, many coccoid cells fluoresced green. The extended resistance to the uptake of PI in this experiment is expected, as culturability of $H$. pylori also increases when it is exposed to BHIB instead of water. Adams et al., however, used this method to evaluate viability of planktonic H. pylori in a natural freshwater environment. Results also indicated that the pathogen keeps membrane integrity for at least $100 \mathrm{~h}$ (but for lower temperatures), which implies that the pathogen viability is not increased when attached to surfaces.

\section{Morphology and aggregation of Helicobacter pylori in different materials and in the planktonic phase}

The proportion of coccoid bacteria in relation to the other forms varied clearly with the material. Whereas for polymeric materials, such as PP and PVC, coccoid or U-shaped morphology represented $80-90 \%$ of the total number of cells after $48 \mathrm{~h}$ of exposure, and approximately 95\% after $192 \mathrm{~h}$, for copper it never exceeded 50\% even after $192 \mathrm{~h}$ (Fig. 2). For the remaining materials, glass, SS316 and SS304 the proportion of coccoid cells after $192 \mathrm{~h}$ ranged between $70 \%$ and $85 \%$. The detection of spiral morphology in the planktonic phase occurred until the end of the experiment, but most of the bacteria (approximately 90\%) assumed the coccoid morphology after only $48 \mathrm{~h}$.

Observations from both SEM and EF show that H. pylori is able to form aggregates on the surface of the different substrata. The structure and abundance of these aggregates also varied with the support material. For instance, copper promoted the accumulation of large numbers of bacteria (more than 50 cells), either in monolayer or in several layers after $96 \mathrm{~h}$. Agglomerates of a medium size (10-50 cells) could be found in PP and PVC after the same time, but were mostly constituted by cocci or U-shaped bacteria and disposed in a monolayer. Large aggregates were not detected before $96 \mathrm{~h}$ for any material and were nonexistent in the planktonic phase during the
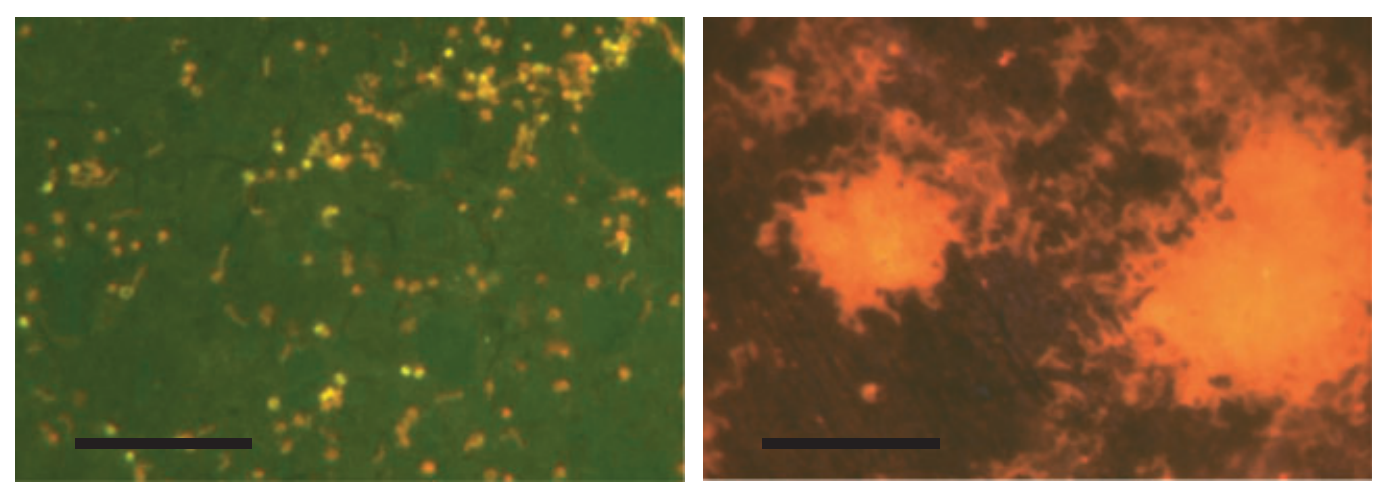

Figure 1 Epifluorescence microscopy images of Syto9/PI stained Helicobacter pylori on SS304 after $48 \mathrm{~h}$ (left), and of an agglomerate of H. pylori cells in copper after $192 \mathrm{~h}$ (right). Bars, $10 \mu \mathrm{m}$. 

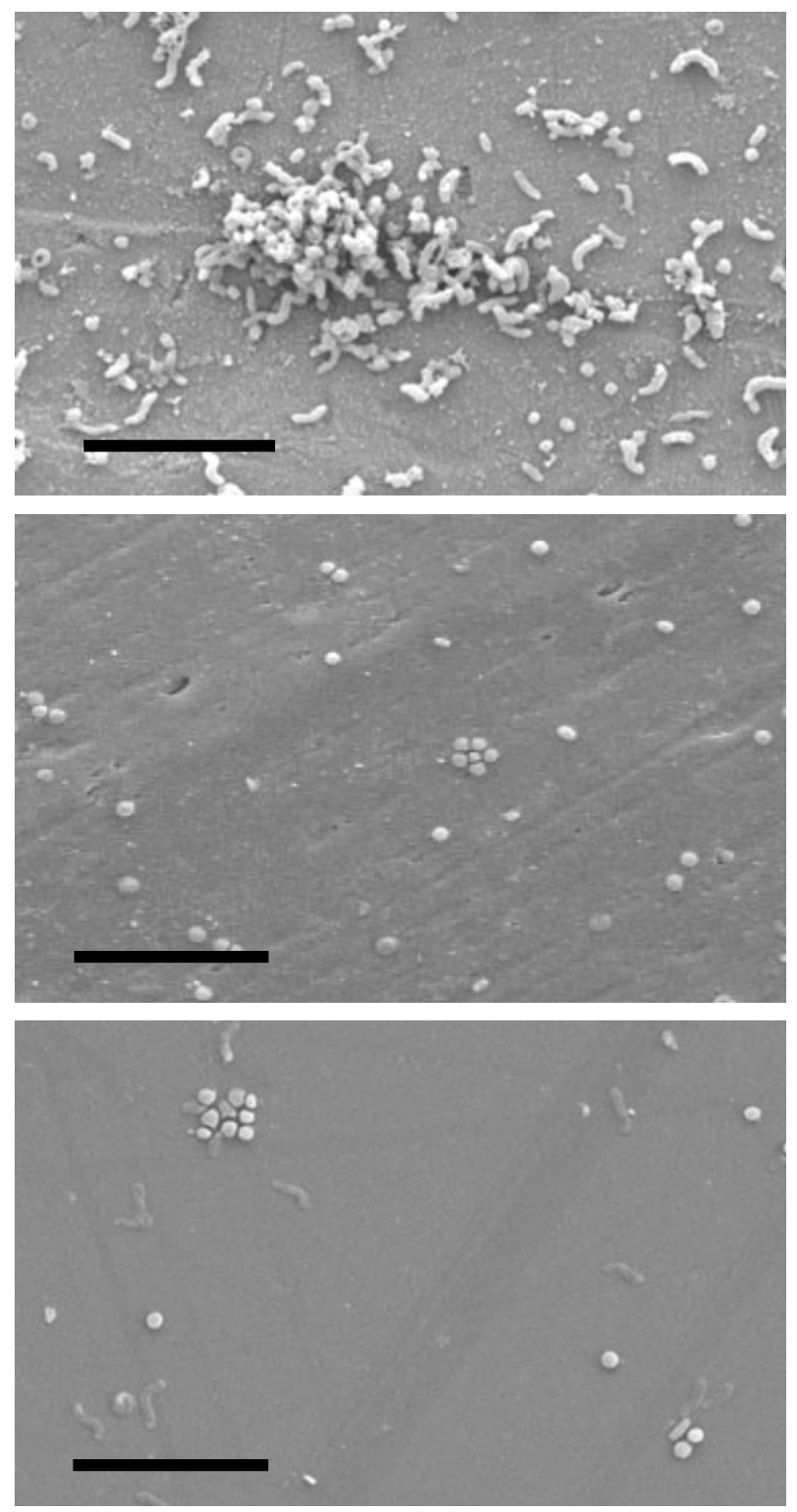

Figure 2 Scanning electron microscope images obtained for Helicobacter pylori adhesion after $192 \mathrm{~h}$ on copper (top), polyvinyl chloride (middle) and glass (bottom). Notice the higher percentage of curved bacilli and the 3-D structure present on the copper surface. Bar, $10 \mu \mathrm{m}$.

time course of the experiment. Smaller aggregates of less than 10 cells were ubiquitous in all materials and could be sparsely found in the planktonic phase after only $2 \mathrm{~h}$. After 2 months, on the copper and SS304 substrata, most of the bacteria were arranged in the form of large aggregates (data not shown). An X-ray microanalysis of the copper substrata showed that these aggregates were mostly present in the oxidized parts of these surfaces.

\section{Discussion}

The degree of bacterial adhesion after the steady state was reached was found to be in the same order of magnitude and not statistically significant to all plumbing material substrata, revealing that under the conditions of the experiment, the type of material is not a determinant factor in the number of total cells adhered. In previous works, material composition was a much more important factor in the attachment of pathogens (Assanta et al. 2002a,b). There was also little impact of the material on the numbers of cultivable attached bacteria. In an earlier study, Rogers et al. (1994) highlighted the importance of this parameter by showing that numbers of Legionella pneumophila ranged from $0 \mathrm{CFU} \mathrm{cm} \mathrm{cm}^{-2}$ for copper to $2132 \mathrm{CFU} \mathrm{cm}{ }^{-2}$ for PVC at $20^{\circ} \mathrm{C}$ and under shear stress.

The relationship between the culturability status of the bacteria and ability to attach to SS304 was studied to verify whether the cell suffers some type of physiological/ morphological modification when entering the noncultivable state that prevents it from attaching. The attachment levels of $H$. pylori to SS304 increased up to $96 \mathrm{~h}$, regardless of the loss of culturability after only $6 \mathrm{~h}$. Although it could be argued that the lower attachment rate after the $6 \mathrm{~h}$ could be because of viable bacteria under the limit of detection, it is much more likely that the attachment is related to the free area available on the surface. In fact, this logarithmic type curve is typical in studies assessing the attachment of the bacteria to surfaces either for heterotrophic consortia or monospecies experiments (Rogers et al. 1994). It is therefore unlikely that the rate of attachment to surfaces is related with the culturability state of the bacterium.

Different materials induced different responses from H. pylori in terms of cell morphology. Because spiral shape is usually associated with a more active form of the cell (Anderson and Wadstrom 2001), the maintenance for longer of spiral morphology of water-stressed $H$. pylori when adhered to copper surfaces can imply that copper provides some sort of protective microenvironment or essential nutrient to the pathogen. Indeed, H. pylori is one of the few bacteria that has been shown to possess a copper transporter system (Ge et al. 1995), which could suggest a higher tolerance of the bacterium for this heavy metal. However, Syto9/PI analysis and cultivation methods indicated that $H$. pylori was in a nonviable state when attached to any of the surfaces after a relatively short length of time. Taking into account these results, the spiral shape maintenance of in copper can also be interpreted as a fast, biocidal effect of the metal upon the pathogen, killing the cell before it has time to undergo the shape modification. 
During the time course of the experiment large aggregates were only found adhered to materials, especially copper, but it has already been observed that $H$. pylori would aggregate in the planktonic phase after longer times (Shahamat et al. 1993). This was also observed in our study but only at times of water exposure of more than 1 month. Aggregation has been considered as one of the mechanisms of the cell to subsist for longer in hostile environments (Davey and O'toole 2000), and this evidence can therefore point to plumbing materials as a more favourable place for $H$. pylori persistence.

This work has highlighted the ability of $H$. pylori to adhere to different plumbing materials, which would support the theory of a drinking water route for the transmission of the pathogen. Copper surfaces are especially suitable for the maintenance of the bacteria in the spiral form, as well as for the formation of a larger number of agglomerates in the surface. However, the physiological state of $H$. pylori under those conditions, as determined by Syto9/PI viability and culture medium experiments, has indicated that most of the bacteria attached have a compromised membrane and are in a noncultivable state. It would be expected that the formation of aggregates and maintenance of a spiral morphology required the cell to be in a viable form, but these data suggest that these events can occur with inactive forms of cells and be solely explained by physical processes invoked, for example, in the Derjaguin-LandauVerwey-Overbeek (DLVO) theory of cell attachment. Because it has been shown that in some cases, simple in vitro studies, utilizing only one or a few species, are poor models for adhesion and colonization in natural environments (Warren et al. 1992), studies involving natural heterotrophic microbial flora will be performed in the sequence of this work. Additionally, as only one culture collection strain was tested, fresh clinical isolates of $H$. pylori will also be studied under the same conditions for further confirmation of the results obtained here.

\section{Acknowledgements}

We would like to acknowledge Sofia Bragança for supplying some of the pipe materials used in this study. This work was supported by the Fundação para a Ciência e Tecnologia (PhD grant SFRH/BD/4705/2001 and Project POCTI/35849/ESP/2000) and by the European Commission Research Project SAFER (Contract $\mathrm{n}{ }^{\circ}$ EVK1-CT2002-00108). Disclaimer: Authors are solely responsible for the work and the work presented does not represent the opinion of the Community and the Community is not responsible for the use that might be made of the data appearing therein.

\section{References}

Adams, B.L., Bates, T.C. and Oliver, J.D. (2003) Survival of Helicobacter pylori in a natural freshwater environment. Appl Environ Microbiol 69, 7462-7466.

Anderson, L.P. and Wadstrom, T. (2001) Basic bacteriology and culture. In Helicobacter pylori: Physiology and Genetics ed. Hazell, S.L. pp. 27-38. Washington, DC: ASM press.

Assanta, M.A., Roy, D., Lemay, M.J. and Montpetit, D. (2002a) Attachment of Arcobacter butzleri, a new waterborne pathogen, to water distribution pipe surfaces. J Food Prot 65, 1240-1247.

Assanta, N.A., Roy, D., Lemay, M.J. and Montpetit, D. (2002b) Evidence for Escherichia coli O157: H7 attachment to water distribution pipe materials by scanning electron microscopy. J Food Prot 65, 1970-1975.

Azevedo, N.F., Pacheco, A.P., Vieira, M.J. and Keevil, C.W. (2004) Nutrient shock and incubation atmosphere influence recovery of culturable Helicobacter pylori from water. Appl Environ Microbiol 70, 490-493.

Azevedo, N.F., Vieira, M.J. and Keevil, C.W. (2003a) Development of peptide nucleic acid probes to detect Helicobacter pylori in diverse species potable water biofilms. In Biofilm Communities: Order from Chaos? ed. McBain, A., Allison, D., Brading, M., Rickard, A., Verran, J. and Walker, J. pp. 105-112. Cardiff: BioLine.

Azevedo, N.F., Vieira, M.J. and Keevil, C.W. (2003b) Establishment of a continuous model system to study Helicobacter pylori survival in potable water biofilms. Water Sci Technol 47, 155-160.

Boulos, L., Prevost, M., Barbeau, B., Coallier, J. and Desjardins, R. (1999) LIVE/DEAD (R) BacLight (TM): application of a new rapid staining method for direct enumeration of viable and total bacteria in drinking water. J Microbiol Methods 37, 77-86.

Bunn, J.E., MacKay, W.G., Thomas, J.E., Reid, D.C. and Weaver, L.T. (2002) Detection of Helicobacter pylori DNA in drinking water biofilms: implications for transmission in early life. Lett Appl Microbiol 34, 450-454.

Citterio, B., Casaroli, A., Pierfelici, L., Battistelli, M., Falcieri, E. and Baffone, W. (2004) Morphological changes and outer membrane protein patterns in Helicobacter pylori during conversion from bacillary to coccoid form. Microbiologica 27, 353-360.

Cole, S.P., Harwood, J., Lee, R., She, R. and Guiney, D.G. (2004) Characterization of monospecies biofilm formation by Helicobacter pylori. J Bacteriol 186, 3124-3132.

Davey, M.E. and O'toole, G.A. (2000) Microbial biofilms: from ecology to molecular genetics. Microbiol Mol Biol Rev 64, 847-867.

Ge, Z.M., Hiratsuka, K. and Taylor, D.E. (1995) Nucleotidesequence and mutational analysis indicate that 2 Helicobacter-pylori genes encode a p-type ATPase and a cation-binding protein associated with copper transport. Mol Microbiol 15, 97-106. 
Hegarty, J.P., Dowd, M.T. and Baker, K.H. (1999) Occurrence of Helicobacter pylori in surface water in the United States. J Appl Microbiol 87, 697-701.

Karita, M., Teramukai, S. and Matsumoto, S. (2003) Risk of Helicobacter pylori transmission from drinking well water is higher than that from infected intrafamilial members in Japan. Dig Dis Sci 48, 1062-1067.

Keevil, C.W. (2003) Pathogens in environmental biofilms. In The Encyclopaedia of Environmental Microbiology ed. Bitton, G. pp. 2339-2356. New York: Wiley.

Kerr, C.J., Osborn, K.S., Robson, G.D. and Handley, P.S. (1999) The relationship between pipe material and biofilm formation in a laboratory model system. J Appl Microbiol 85, 29s-38s.

Lu, Y.Z., Redlinger, T.E., Avitia, R., Galindo, A. and Goodman, K. (2002) Isolation and genotyping of Helicobacter pylori from untreated municipal wastewater. Appl Environ Microbiol 68, 1436-1439.

Mackay, W.G., Gribbon, L.T., Barer, M.R. and Reid, D.C. (1999) Biofilms in drinking water systems: a possible reservoir for Helicobacter pylori. J Appl Microbiol 85, 52s-59s.

Mazari-Hiriart, M., Lopez-Vidal, Y., Castillo-Rojas, G., de Leon, S.P. and Cravioto, A. (2001) Helicobacter pylori and other enteric bacteria in freshwater environments in Mexico City. Arch Med Res 32, 458-467.

Mitchell, H. and Megraud, F. (2002) Epidemiology and diagnosis of Helicobacter pylori infection. Helicobacter 7(Suppl. 1), 8-16.

Moshkowitz, M., Gorea, A., Arber, N., Konikoff, F., Berger, S. and Gilat, T. (1994) Morphological transformation of Helicobacter-pylori during prolonged incubation - association with decreased acid resistance. J Clin Pathol 47, 172-174.

Park, S.R., Mackay, W.G. and Reid, D.C. (2001) Helicobacter sp. recovered from drinking water biofilm sampled from a water distribution system. Water Res 35, 1624-1626.
Parsonnet, J., Shmuely, H. and Haggerty, T. (1999) Fecal and oral shedding of Helicobacter pylori from healthy infected adults. J Am Med Assoc 282, 2240-2245.

Pedersen, K. (1990) Biofilm development on stainless-steel and PVC surfaces in drinking-water. Water Res 24, 239-243.

Rogers, J., Dowsett, A.B., Dennis, P.J., Lee, J.V. and Keevil, C.W. (1994) Influence of temperature and plumbing material selection on biofilm formation and growth of Legionella-pneumophila in a model potable water-system containing complex microbial-flora. Appl Environ Microbiol 60, 1585-1592.

Saito, N., Konishi, K., Sato, F., Kato, M., Takeda, H., Sugiyama, T. and Asaka, M. (2003) Plural transformation-processes from spiral to coccoid Helicobacter pylori and its viability. J Infect 46, 49-55.

Shahamat, M., Mai, U., Paszkokolva, C., Kessel, M. and Colwell, R.R. (1993) Use of autoradiography to assess viability of Helicobacter pylori in water. Appl Environ Microbiol 59, 1231-1235.

Stevenson, T.H., Lucia, L.M. and Acuff, G.R. (2000) Development of a selective medium for isolation of Helicobacter pylori from cattle and beef samples. Appl Environ Microbiol 66, 723-727.

Warren, T.M., Williams, V. and Fletcher, M. (1992) Influence of solid-surface, adhesive ability, and inoculum size on bacterial-colonization in microcosm studies. Appl Environ Microbiol 58, 2954-2959.

Watson, C.L., Owen, R.J., Said, B., Lai, S., Lee, J.V., SurmanLee, S. and Nichols, G. (2004) Detection of Helicobacter pylori by PCR but not culture in water and biofilm samples from drinking water distribution systems in England. J Appl Microbiol 97, 690-698.

West, A.P., Millar, M.R. and Tompkins, D.S. (1990) Survival of Helicobacter-pylori in water and saline. J Clin Pathol 43, 609-609. 